\title{
International Archives of
}

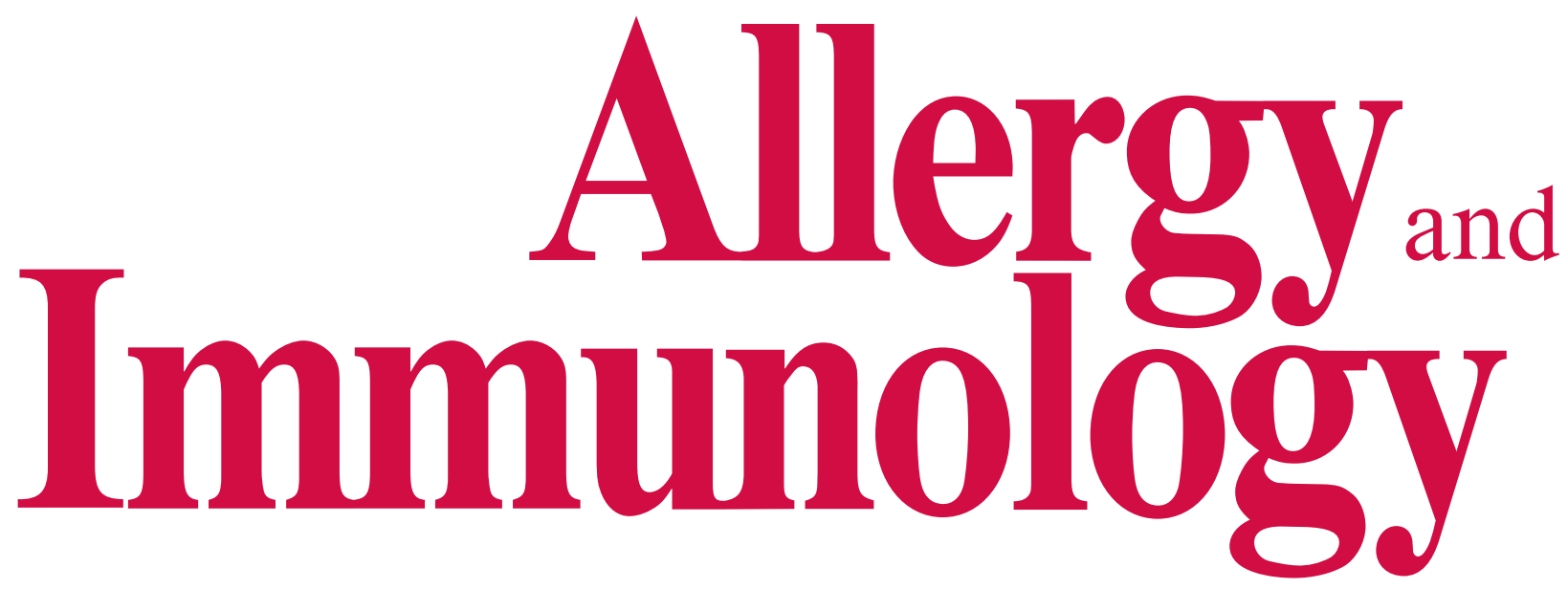

Official Journal of the

Collegium Internationale Allergologicum<smiles>c1ccc(C23CC4CC(CC(C4)C2)C3)cc1</smiles>

\section{Editorial}

97 In the Summertime When the Weather Is Fine

Fernández-Caldas, E. (Madrid/Tampa. Fla.)

Review

99 Non-Pro-Vitamin A and Pro-Vitamin A Carotenoids in Atopy Development

Rühl, R. (Debrecen)

Molecules and Cells in Allergy

116 Nasal High-Mobility Group Box-1 Protein in Children with Allergic Rhinitis

Salpietro, C.; Cuppari, C.; Grasso, L. (Messina); Tosca, M.A. (Genoa); Miraglia Del Giudice, M. (Naples); La Rosa, M. (Catania); Marseglia, G.L. (Pavia); Salpietro, A. (Messina); Ciprandi, G. (Genoa)
122 Inconclusive Evidence for or against Positive Antigen Selection in the Shaping of Human Immunoglobulin E Repertoires: A Call for New Approaches Levin, M.; Ohlin, M. (Lund)

127 Bed Bug Saliva Causes Release of Monocytic Inflammatory Mediators: Plausible Cause of Cutaneous Bite Reactions

Goddard, J. (Mississippi State, Miss.); Hasenkampf, N. (Covington, La.); Edwards, K.T. (Mississippi State, Miss.); de Shazo, R. (Jackson, Miss.); Embers, M.E. (Covington, La.)

Mechanisms of Allergy

131 Phenotypic Correlations between Monocytes and CD4+ T Cells in Allergic Patients

Moniuszko, M.; Kowal, K.; Jeznach, M.; Rusak, M.; Dabrowska, M.; Bodzenta-Lukaszyk, A. (Bialystok) 


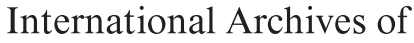 \\ Allergy
Immunology}

(Continued from front cover)

142 Characterization of Candidate Anti-Allergic Probiotic Strains in a Model of Th2-Skewed Human Peripheral Blood Mononuclear Cells

Holvoet, S.; Zuercher, A.W.; Julien-Javaux, F.; Perrot, M.; Mercenier, A. (Lausanne)

\section{Different Frequencies of Tc17/Tc1 and Th17/Th1 Cells in} Chronic Spontaneous Urticaria

Lopes, A.; Machado, D.; Pedreiro, S.; Henriques, A.; Silva, I.; Tavares, B.; Inácio, M.J.; Chieira, C.; Martinho, A.; Pais, M.L.; Pereira, C.; Paiva, A. (Coimbra)
Clinical Allergology

163 Asthmatic Response to Milk Ingestion Challenge in Adults: A Comparison of the Open and Double-Blind Challenges

Pelikan, Z. (Breda)

174 Immunotherapy with Commercial Venoms Is Efficacious for Anaphylactic Reactions to Vespa orientalis Stings Goldberg, A.; Shefler, I. (Kfar Saba); Panasoff, J. (Haifa); Paitan, Y.; Confino-Cohen, R. (Kfar Saba)

181 Mild Asthma and Chronic Bronchitis Seem to Influence Functional Exercise Capacity: A Multi-Case Control Study

Marcon, A.; Girardi, P.; Ferrari, M.; Olivieri, M.; Accordini, S.; Bombieri, C.; Bortolami, O. (Verona); Braggion, M. (Venice); Cappa, V.; Cazzoletti, L.; Locatelli, F.; Nicolis, M.; Perbellini, L.; Sembeni, S.; Verlato, G.; Zanolin, M.E.; de Marco, R. (Verona)

189 Mild Improvement in Symptoms and Pulmonary Function in a Long-Term Follow-Up of Patients with Toluene Diisocyanate-Induced Asthma

Talini, D.; Novelli, F.; Bacci, E.; Costa, F.; Dente, F.L.;

Di Franco, A.; Malagrinò, L.; Vagaggini, B.; Paggiaro, P. (Pisa) 
Official Journal of the

Collegium Internationale Allergologicum

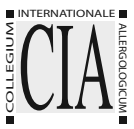

\section{International Archives of Allergy
Immunology}

Founded 1950 by D. Harley, P. Kallós, W. Löfler and F.W. Wittich Continued by E.A. Brown (1952-1954), W. Kaufman (1955-1967), F. Hahn (1961-1972), H.C. Goodman (1963-1975),

R.R.A. Coombs (1955-1984), Z. Trnka (1972-1987), P. Kallós (1950-1988),

G.B. West (1959-1991), J. Bienenstock (1990-1991), L.Å. Hanson (1981-1991),

K. Kano (1982-1991), F. Milgrom (1965-1991), K. Rother (1982-1991),

G. Wick (1991-1997), B. Grubeck-Loebenstein (1991-1997), D. Kraft (1998-2002)

\section{Editors-in-Chief}

R. Valenta, Vienna

B. Bohle, Vienna

\section{Associate Editors}

K. Blaser, Davos

P.-J. Bousquet, Montpellier

A.W. Burks, Chapel Hill, N.C.

D. Dombrowicz, Lille

H. Garn, Marburg

P. Gevaert, Ghent

T. Jakob, Freiburg

P. O'Byrne, Hamilton, Ont.

R. Pawankar, Tokyo

W.F. Pickl, Vienna

A. Radbruch, Berlin

M. Röllinghoff, Erlangen

H. Saito, Tokyo

C.B. Schmidt-Weber, Munich

T. Schwarz, Kiel

W. Thomas, Perth

M. Triggiani, Naples

R. van Ree, Amsterdam

Consulting Editor for Biostatistics

M. Kundi, Vienna

\section{Editorial Board}

W. Aberer, Graz

M. Akdis, Davos

I.J. Ansotegui, Belfast

L.K. Arruda, Ribeirão Preto

C.E. Baena-Cagnani, Cordoba

T. Biedermann, Tübingen

S.C. Bischoff, Stuttgart

$\mathrm{H}$. Breiteneder, Vienna

G.W. Canonica, Genova

M. Capron, Lille

M.D. Chapman, Charlottesville, Va.

K.Y. Chua, Singapore

M. Ebisawa, Kanagawa

E. Fernández-Caldas, Seefeld

F. Ferreira, Salzburg

H. Grönlund, Stockholm

K.T. HayGlass, Winnipeg, Man.

K. Hoffmann-Sommergruber,

Vienna

P.G. Holt, Perth

F. Horak, Vienna

E. Jensen-Jarolim, Vienna

M. Jutel, Wroclaw

D. Kabelitz, Kiel

A. Kapp, Hannover

D. Kraft, Vienna

M. Larché, Hamilton, Ont.

E. Maggi, Florence

R.N. Maini, London

A. Mari, Latina
S.F. Martin, Freiburg

M. Maurer, Berlin

F. Melchers, Basel

N.G. Papadopoulos, Athens

O. Pérez, Havana City

W.J. Pichler, Bern

T.A.E. Platts-Mills,

Charlottesville, Va.

H. Renz, Marburg/Lahn

N. Rezaei, Teheran

L.J. Rosenwasser, Kansas City, Mo.

K. Roux, Tallahassee, Fla.

J.-M. Saint-Rémy, Leuven

H.A. Sampson, New York, N.Y.

R. Sepiashvili, Moscow

Y. Shoenfeld, Tel Hashomer

H.-U. Simon, Bern

J. Smolen, Vienna

Z. Szépfalusi, Vienna

E. Toubi, Haifa

P. Valent, Vienna

M. van Hage, Stockholm

H. Wekerle, Martinsried

T. Werfel, Hannover

G. Wick, Innsbruck

M. Wickman, Stockholm

U. Wiedermann, Vienna

S. Wöhrl, Vienna

H. Yssel, Montpellier
Printed in Switzerland on acid-free and non-aging paper (ISO 9706) by Reinhardt Druck, Basel
Appears monthly:

3 volumes per year (12 issues) 


\section{Allergy $_{\text {and }}$ Immunology}

\begin{abstract}
'International Archives of Allergy and Immunology' appears monthly and provides a forum for publication of work from all aspects of modern allergology and immunology. Papers considered of special interest will be treated as 'hot topics' and every attempt will be made to publish these especially fast. The Editor-in-Chief, the Managing Editor and a team of internationally established Associate Editors competently covering all fields of allergology and immunology are responsible for the scientific quality of this international core journal. International Archives publishes original work in the fields of allergy, immunopathology and transplantation, cellular immunology, immunogenetics, immunopharmacology and immunoendocrinology, mucosal immunity, immunology of infectious diseases and immunology of connective tissue diseases. In addition, reviews, minireviews, commentaries and opinions on controversial subjects are published regularly. A new system of manuscript submission, reviewing and processing guarantees competent and fair reviewing as well as fast and high quality publication.
\end{abstract}

\section{Submission}

Only papers written in English are considered. Detailed Online Submission Instructions with a link to the Submission Website are at http://www.karger.com/iaa/. Before submitting your manuscript, you are encouraged to review the detailed guidelines at www.karger.com/ iaa_guidelines for specific directions as how to get a manuscript ready for submission. If you should have any problems with your submission, or should you feel the need to submit the paper in a non-electronic form, please contact the editorial office:

S. Karger AG

Editorial Office 'International Archives of

Allergy and Immunology'

PO Box

CH-4009 Basel (Switzerland)

Tel. $\quad+41613061360$

Fax +41613061434

E-Mail e.lieberherr@karger.com

Mailing address for courier deliveries only:

Allschwilerstr. 10

CH-4055 Basel (Switzerland)

Original papers: Submitted manuscripts should be fully documented reports of original research. They must describe significant and original observations to be critically evaluated and, if necessary, repeated.

Short communications: These manuscripts should not contain more than 2 printed pages (i.e. 6,460 characters per page), including an abstract, essential references and not more than 3 tables or figures. Such communications should represent complete, original studies and should be arranged in the same way as full-length manuscripts.

Novel Insights from Clinical Practice (formerly Case Reports): The publication space available for case reports is very limited. The journal only considers case reports with significant new insights or with an extremely unusual and memorable course. Highlighted boxes containing one or two bullet points on 'Established facts' (what is already known) and 'Novel insights' (what new information has been gained) are required and should be placed on the first page of the report. These should be selected so as to reinforce the novelty of the clinical observation. The manuscript should be presented with an abstract (unstructured, max. 200 words), followed by introduction, case report and discussion. Maximum 3 figures.

Review articles, minireviews, opinion articles, controversies and commentaries: Authors who wish to contribute a manuscript to one of these categories should contact the Editor-in-Chief. Minireviews should be focused, brief reports on topics of current interest. Commentaries should offer a more personalized perspective on a topic that will be of interest to the general readership. All contributions to these categories will be subject to Editorial review.

Letters to the Editor concerning work published in the journal may be submitted. They should not exceed 2 manuscript pages including one table or figure.

\section{Conditions}

All manuscripts are subject to editorial review. Manuscripts are received with the explicit understanding that they are not under simultaneous consideration by any other publication. A cover letter with the name, address, and telephone and telefax numbers of the corresponding author must accompany each manuscript. This letter must include a statement that affirms that all authors agree with the submission. Submission of an article for publication implies the transfer of the copyright from the author to the publisher upon acceptance. Accepted papers become the permanent property of International Archives of Allergy and Immunology and may not be reproduced by any means, in whole or in part, without the written consent of the publisher. It is the author's responsibility to obtain permission to reproduce illustrations, tables, etc. from other publications. One of the criteria considered in reviewing manuscripts is the proper treatment of animals. In particular, the use of painful or otherwise noxious stimuli must be carefully and thoroughly justified. Papers that do not meet these criteria will not be accepted for publication.

\section{Conflict of Interest}

Authors are required to disclose any sponsorship or funding arrangements, including that from companies, relating to their research. All authors should disclose any possible conflicts of interest in the cover letter to the editor and at the end of the article.

\section{Plagiarism Policy}

Whether intentional or not, plagiarism is a serious violation. We define plagiarism as a case in which a paper reproduces another work with at least $25 \%$ similarity and without citation.

If evidence of plagiarism is found before/after acceptance or after publication of the paper, the author will be offered a chance for rebuttal. If the arguments are not found to be satisfactory, the manuscript will be retracted and the author sanctioned from publishing $\mathrm{pa}$ pers for a period to be determined by the responsible Editor(s).

\section{Arrangement}

Manuscripts should be written in English and be as concise as possible.

Be sure to display line numbers (1,2,3, and so forth) in the left margin of the manuscript (line numbering can be added from the Page Setup or Format menu of word processing programs). The line numbering should be continuous throughout the entire manuscript, from the title page through to the final page (i.e., do not begin numbering from 1 again at the top of each page).

Title page: The first page of each paper should indicate a concise title, the authors' full names, affiliations and e-mail addresses, the institute where the work was conducted, and a short title for use as running head.

Full address: The exact postal address of the corresponding author complete with postal code must be given at the bottom of the title page. Please also supply phone and fax numbers, as well as an e-mail address.

Key words: Please supply 3-10 key words in English that reflect the content of the paper.

Abstract: Provide on a separate page an abstract of not more than 250 words. This abstract should consist of four paragraphs, labeled Background, Methods, Results, and Conclusions. They should briefly describe, respectively, the problem being addressed in the study, how the study was performed, the salient results, and what the authors conclude from the results.

The text should be arranged in the following sections: Introduction, Material and Methods, Results, Discussion, Acknowledgement, References.

Footnotes: Avoid footnotes. When essential, they are numbered consecutively and typed at the foot of the appropriate page.

Tables and illustrations: Tables and illustrations (both numbered in Arabic numerals) should be prepared on separate pages. Tables require a heading and figures a legend, also prepared on a separate page. For the reproduction of illustrations, only good drawings and original photographs can be accepted; negatives or photocopies cannot be used. Due to technical reasons, figures with a screen background should not be submitted. When possible, group several illustrations on one block for reproduction (max. size $180 \times 223 \mathrm{~mm}$ ) or provide crop marks. Each illustration must be labeled with its number and the author's name. Electronically submitted $\mathrm{b} / \mathrm{w}$ half-tone and color illustrations must have a final resolution of $300 \mathrm{dpi}$ after scaling (final size), line drawings one of $800-1,200$ dpi. Figure files must not be embedded in a document file but submitted separately (see detailed instructions at www.karger.com/iaa/).

\section{Color illustrations}

Online edition: Color illustrations are reproduced free of charge. In the print version, the illustrations are reproduced in black and white. Please avoid referring to the colors in the text and figure legends.

Print edition: Up to 6 color illustrations per page can be integrated within the text at CHF 800.- per page.

Abbreviations: Avoid overuse of abbreviations. Introduce an abbreviation only when the same term occurs three or more times.

\section{KARGER}

E-Mail karger@karger.com www.karger.com
(C) 2013 S. Karger AG, Basel

The Guidelines for Authors are available at: www.karger.com/iaa_Guidelines 
References: In the text identify references by Arabic numerals [in square brackets]. Material submitted for publication but not yet accepted should be noted as 'unpublished data' and not be included in the reference list. The list of references should include only those publications which are cited in the text. Do not alphabetize; number references in the order in which they are firs mentioned in the text. The surnames of the authors followed by initials should be given. There should be no punctuation other than a comma to separate the authors. Preferably, please cite all authors. Abbreviate journal names according to the Index Medicus system. Also see International Committee of Medical Journal Editors: Uniform requirements for manuscripts submitted to biomedical journals (www.icmje.org).

\section{Examples}

(a) Papers published in periodicals: Sun J, Koto $\mathrm{H}$ Chung KF: Interaction of ozone and allergen challenges on bronchial responsiveness and inflammation in sensitised guinea pigs. Int Arch Allergy Immunol 1997;112:191-195.

(b) Papers published only with DOI numbers:

Theoharides TC, Boucher W, Spear K: Serum interleukin-6 reflects disease severity and osteoporosis in mastocytosis patients. Int Arch Allergy Immuno DOI: $10.1159 / 000063858$.

(c) Monographs: Matthews DE, Farewell VT: Using and Understanding Medical Statistics, ed 3, revised. Basel, Karger, 1996.

(d) Edited books: Parren PWHI, Burton DR: Antibodies against HIV-1 from phage display libraries: Mapping of an immune response and progress towards antiviral immunotherapy; in Capra JD (ed): Antibody Engineering. Chem Immunol. Basel, Karger, 1997, vol 65, pp 18-56.

Full address: The exact postal address complete with postal code must be given at the bottom of the title page. Please also supply phone and fax numbers, as well as your e-mail address.
Reference Management Software: Use of EndNote ${ }^{\circledR}$ is recommended for easy management and formatting of citations and reference lists (format setting: Intervirology).

\section{Digital Object Identifier (DOI)}

S. Karger Publishers supports DOIs as unique identifiers for articles. A DOI number will be printed on the title page of each article. DOIs can be useful in the future for identifying and citing articles published online without volume or issue information. More information can be found at www.doi.org.

\section{Supplementary Material}

Supplementary material is restricted to additional data that are not necessary for the scientific integrity and conclusions of the paper. Please note that all supplementary files will undergo editorial review and should be submitted together with the original manuscript. The Editors reserve the right to limit the scope and length of the supplementary material. Supplementary material must meet production quality standards for Web publication without the need for any modification or editing. In general, supplementary files should not exceed $10 \mathrm{MB}$ in size. All figures and tables should have titles and legends and all files should be supplied separately and named clearly. Acceptable files and formats are: Word or PDF files, Excel spreadsheets (only if the data cannot be converted properly to a PDF file), and video files (.mov, .avi, .mpeg).

\section{Author's Choice ${ }^{\mathrm{TM}}$}

Karger's Author's Choice ${ }^{\mathrm{TM}}$ service broadens the reach of your article and gives all users worldwide free and full access for reading, downloading and printing at www.Karger.com. The option is available for a onetime fee of CHF 3000.-, which is a permissible cost in grant allocation. More information can be found at www.karger.com/authors_choice.

\section{NIH-Funded Research}

The U.S. National Institutes of Health (NIH) mandates under the NIH Public Access Policy that final, peer- reviewed manuscripts appear in its digital database within 12 months of the official publication date. As a service to authors, Karger submits your manuscript on your behalf to PubMed Central (PMC) immediately upon publication. It usually receives a PMCID within approximately a month and will appear in PMC after 12 months. For those selecting our premium Author's ChoiceTM service, the usual embargo will be overridden, accelerating the accessibility of your work.

\section{Self-Archiving}

Karger permits authors to archive their pre-prints (i.e. pre-refereeing) or post-prints (i.e. final draft postrefereeing) on their personal or institution's servers, provided the following conditions are met: Articles may not be used for commercial purposes, must be linked to the publisher's version, and must acknowledge the publisher's copyright. Authors selecting Karger's Author's Choice ${ }^{\mathrm{TM}}$ feature, however, are also permitted to archive the final, published version of their article, which includes copyediting and design improvements as well as citation links.

\section{Page Charges}

There are no page charges for papers of 5 or fewer printed pages (including tables, illustrations and references) Each additional complete or partial page is charged to the author at CHF 325.-. The allotted size of a paper is 5 printed pages $(6,460$ characters per page), which is equal to approx. 14 manuscript pages including tables, illustrations and references.

\section{Proofs}

Unless indicated otherwise, proofs are sent to the corresponding author and should be returned with the least possible delay. Alterations other than the correction of printer's errors are charged to the author.

\section{Reprints}

Order forms and a price list are sent with the proofs. Orders submitted after the issue is printed are subject to considerably higher prices.

\section{KARGER}

(C) 2013 S. Karger AG, Basel

The Guidelines for Authors are available at: www.karger.com/iaa_Guidelines 


\section{Allergy ${ }_{\text {and }}$ \\ Immunology}

ISSN Print Edition: 1018-2438

ISSN Online Edition: 1423-0097

Journal Homepage: www.karger.com/iaa

Publication Data: 'International Archives of Allergy and Immunology' is published 12 times a year. Volumes 160-162, each with 4 issues, appear in 2013.

Copyright: (c) 2013 S. Karger AG, Basel (Switzerland). All rights reserved. No part of this publication may be translated into other languages, reproduced or utilized in any form or by any means, electronic or mechanical, including photocopying, recording, microcopying, or by any information storage and retrieval system, without permission in writing from the publisher or, in the case of photocopying, direct payment of a specified fee to the Copyright Clearance Center.

Disclaimer: The statements, opinions and data contained in this publication are solely those of the individual authors and contributors and not of the publisher and the editor(s). The appearance of advertisements in the journal is not a warranty, endorsement, or approval of the products or services advertised or of their effectiveness, quality or safety. The publisher and the editor(s) disclaim responsibility for any injury to persons or property resulting from any ideas, methods, instructions or products referred to in the content or advertisements.
Subscription Rates: Subscriptions run for a full calendar year. Prices are given per year. Personal subscription

Print or Online

CHF 172.-

EUR 139-

USD 170.00

Print+Online combined

EUR 256.-

USD 314.00

postage and handling (added to print and print+online)

CHF 86.40 Europe, CHF 124.80 Overseas

EUR 67.20

USD 115.20

Institutional subscription:

Print or Online

Print+Online combined

CHF 5238.-

EUR 4224.-

CHF 5763.-

postage and handling (added to print and print+online)

CHF 108.- Europe, CHF 156.- Overseas

EUR 84.-

USD 144.00

Airmail surcharge: CHF 105.- / USD 99.00
Back Volumes and Single Issues: Information on availability and prices of single print issues and print or electronic back volumes can be obtained from Customer Service atservice@karger.com.

Bibliographic Indices: This journal is regularly listed in bibliographic services, including Current Contents ${ }^{\circledR}$ and PubMed/MEDLINE.

Photocopying: This journal has been registered with the Copyright Clearance Center (CCC), as indicated by the code appearing on the first page of each article. For readers in the US, this code signals consent for copying of articles for personal or internal use, or for the personal or internal use of specific clients, provided that the stated fee is paid per copy directly to

Copyright Clearance Center Inc.

222 Rosewood Drive

Danvers, MA 01923 (USA)

A copy of the first page of the article must accompany payment. Consent does not extend to copying for general distribution, for promotion, for creating new works, or for resale. In these cases, specific written permission must be obtained from the copyright owner,

S. Karger AG, P.O. Box

CH-4009 Basel (Switzerland).
Subscription Orders:

Orders can be placed at agencies,

bookstores, directly with the Publisher

\section{S. Karger AG}

Medical and Scientific Publishers

Allschwilerstrasse 10

$\mathrm{CH}-4009$ Basel

Switzerland

$+41613061111$

f: +41613061234

e: karger@karger.com

w: www.karger.com

(for courier services only:

Allschwilerstrasse 10

$\mathrm{CH}-4055$ Basel) or further Karger offices

or representatives:

Germany

S. Karger GmbH

Postfach

79095 Freiburg

Deutschland

(Hausadresse: Wilhelmstrasse 20A,

79098 Freiburg)

$\mathrm{t}: \quad+49761452070$

f: +497614520714

e: information@karger.de

w: www.karger.de

\section{Japan}

Karger Japan, Inc

Shiba Daimon Asahi Bldg. 2F

1-2-23 Shiba Daimon

Minato-ku

Tokyo 105-0012

Japan

t: +81364356242

f: +81364356244

e: publisher@karger.jp

w: www.karger.jp
USA

S. Karger Publishers, Inc.

26 West Avon Road

P.O. Box 529

Unionville, CT 06085

USA

Toll free: +18008285479

t: +18606757834

f. +18606757302

e: karger@snet.net

France

Librairie Médi-Sciences Sar

36, bd de Latour-Maubourg

75007 Paris

France

t: $+33(0) 145514258$

f: $\quad+33(0) 145560780$

f: $+33(0) 145560780$
e: librairie@medi-sciences.f

w: www.medi-sciences.fr
South East Asia, China and Taiwan Karger Regional Office (Malaysia)

CEO Suite Kuala Lumpur

Quill 7, 27th Floor

Jalan Stesen Sentral 5

KL Sentral

Kuala Lumpur 50470

Malaysia

t. +60327766803

f: +60327766999

e: service@karger.cn; r.chew@karger.cn

\section{Karger China}

10th Floor, Twin Towers (East)

B12 Jianguomenwai Avenue

Beijing 100022

China

$\mathrm{t}: \quad+861051235033$

f: +861051235122

e: service@karger.cn; r.chew@karger.cn

w: www.karger.cn

India, Bangladesh, Sri Lanka

Medscience India

Plot No. 17, Yusuf Sarai Market

B.L. Glass Building, 2nd Floor

Sri Aurobindo Marg

New Delhi 110016

India

t: +911146029633

f: +911146029634

c: +919891052128

e: medsci.india@gmail.com

Change of Address:

Both old and new address should be sent

to the subscription source.

\section{KARGER}

E-Mail karger@karger.com www.karger.com
(C) 2013 S. Karger AG, Basel

The Guidelines for Authors are available at: www.karger.com/iaa_Guidelines 


\section{Contents}

See the journal website for contents

KARGER Basel $\bullet$ Freiburg $\cdot$ Paris $\bullet$ London $\bullet$ New York $\cdot$ New Delhi $•$ Bangkok Beijing $\cdot$ Tokyo $\cdot$ Kuala Lumpur $\cdot$ Singapore $\bullet$ Sydney 


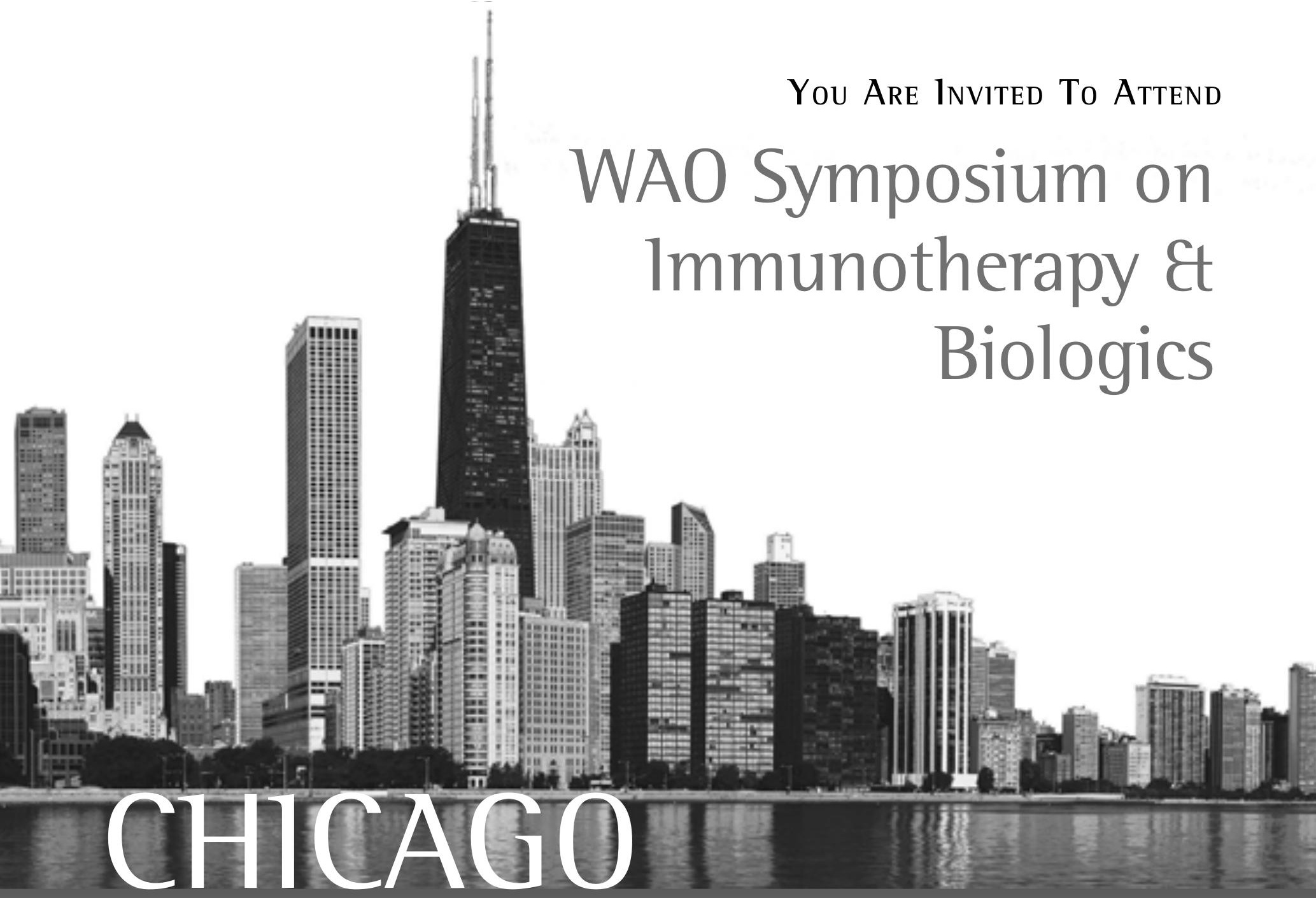

13-14 December 2013 - Chicago, ll, United States

Don't miss the opportunity to participate in the first global meeting of its kind! ATTENDANCE WILL BE LIMITED!

The Symposium will welcome basic and translational scientists, clinical immunologists, allergists and researchers interested in exploring the exciting field of lmmunotherapy and Biologics. www.worldallergy.org/symposium2013/ 


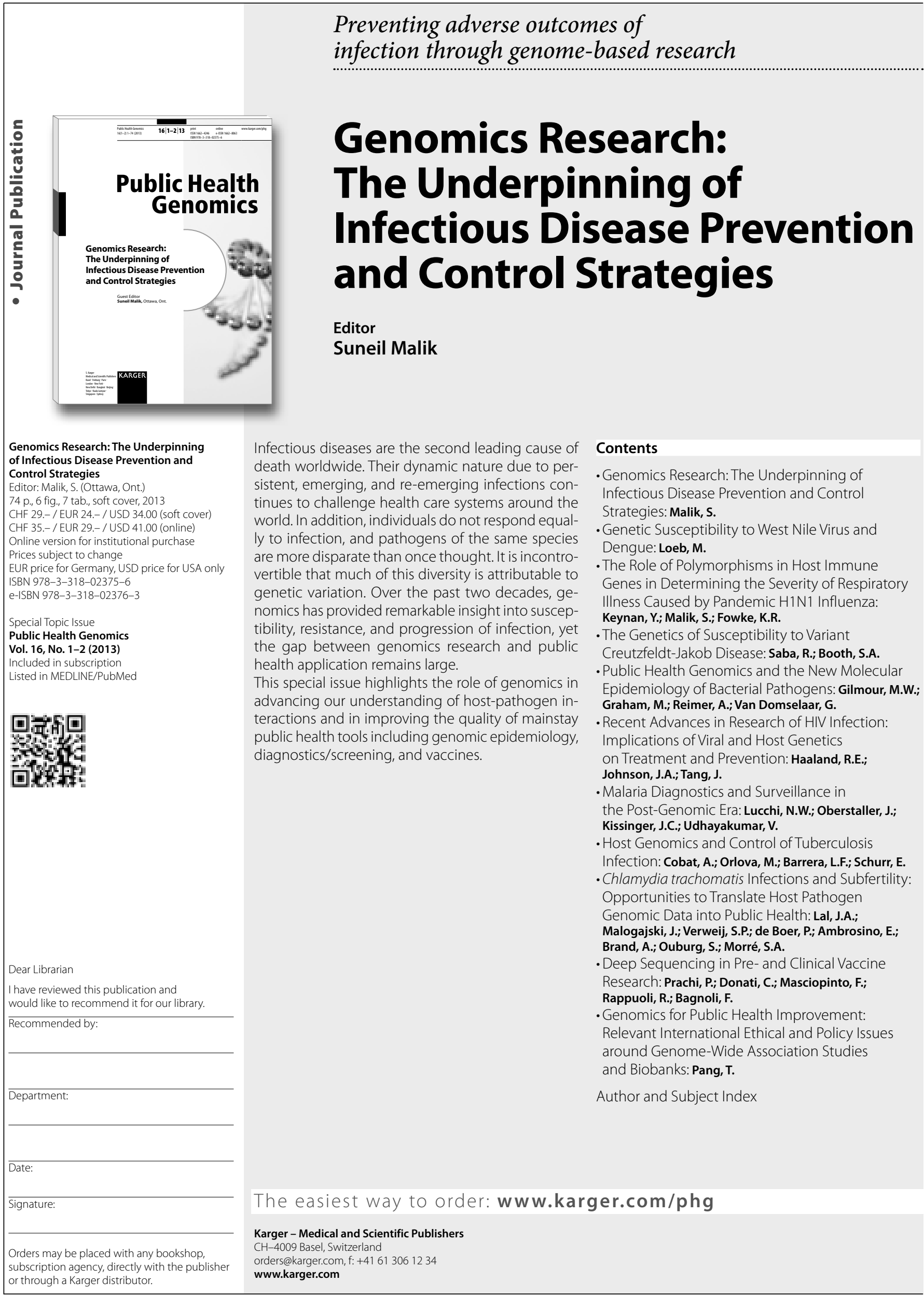




\section{A complete guide to progress in thoracic medicine}

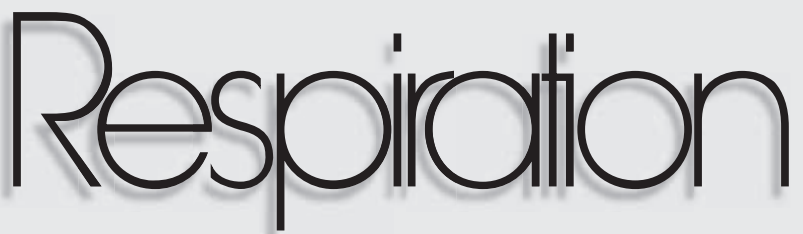

Official Journal of the European Association for Bronchology and Interventional Pulmonology (EAB) and the Swiss Society for Pneumology (SGP)

Editor-in-Chief
F.J.F. Herth, Heidelberg
Associate Editors
I. Adcock, London
K.E. Bloch, Zurich
A. Boehler, Zurich
D. Bouros, Alexandropoulis
G. Colice, Washington, D.C.
V. Cottin, Lyon
C. Dooms, Leuven
E. Eber, Graz

S. Gasparini, Ancona

J. Hammer, Basel

J. Johnston, Vancouver, B.C.

C.F. Koegelenberg,

Cape Town

M. Lommatzsch, Rostock

M. Miravitlles, Barcelona

J. Müller-Quernheim,

Freiburg

L.P. Nicod, Lausanne

D. Olivieri, Parma

W. Randerath, Solingen
P. Shah, London

S. Siddiqui, Leicester

T. Terashima, Ichikawa

0.S. Usmani, London

S. van Eeden,

Vancouver, B.C.

K. Yasufuku, Toronto, Ont.
Impact Factor: 2.258

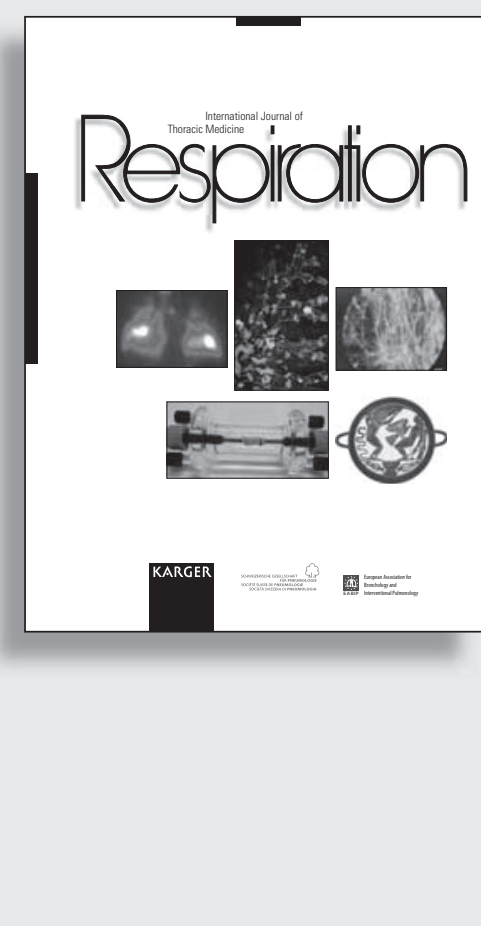

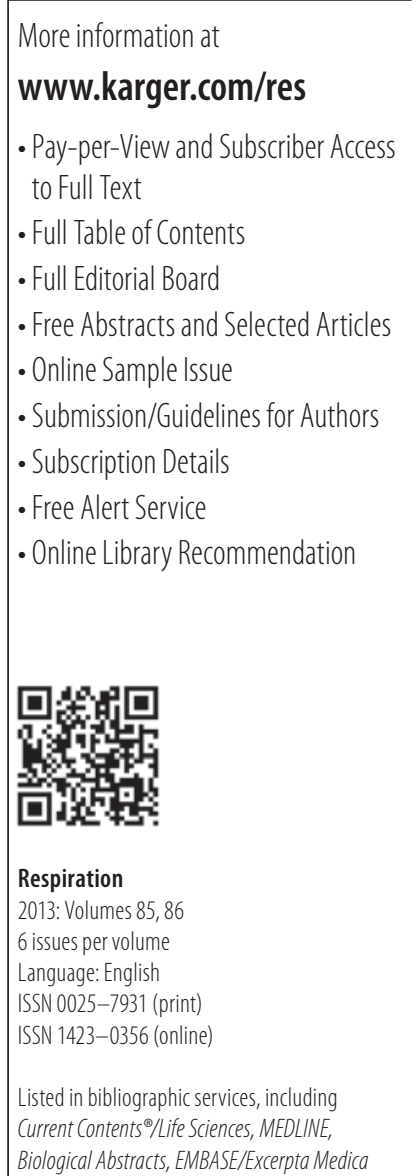

\section{Selected contributions}

- Smoking Prevention and Cessation in the Africa and Middle East Region: A Consensus Draft Guideline for Healthcare Providers - Executive Summary: Ali, A.Y.M. (Abu Dhabi); Safwat, T. (Cairo); Onyemelukwe, G. (Zaria); Al Otaibi, M.A.A. (Ras Al Khaimah); Amir, A.A. (Jeddah); Nawas, Y.N. (Amman); Aouina, H. (Tunis); Afif, M.H. (Casablanca); Bolliger, C.T. (Cape Town)

- Novel Intrapleural Therapies for Malignant Diseases: Haas, A.R.; Sterman, D.H. (Philadelphia, Pa.)

- Efficacy of Bronchoscopic Thermal Vapor Ablation and Lobar Fissure Completeness in Patients with Heterogeneous Emphysema: Gompelmann, D.; Heussel, C.P.; Eberhardt, R. (Heidelberg); Snell, G. (Melbourne, Vic.); Hopkins, P. (Chermside, Old.); Baker, K. (lowa City, lowa); Witt, C. (Berlin); Valipour, A. (Vienna); Wagner, M. (Nürnberg); Stanzel, F. (Hemer); Egan, J. (Dublin); Ernst, A. (Boston, Mass.); Kesten, S. (Tustin, Calif.); Herth, F.J.F. (Heidelberg)

- Acute Exacerbation of Idiopathic Pulmonary Fibrosis: Outcome and Prognostic Factors: Simon-Blancal, V.; Freynet, 0.; Nunes, H.; Bouvry, D.; Naggara, N.; Brillet, P.-Y. (Bobigny); Denis, D. (Rennes); Cohen, Y.; Vincent, F.; Valeyre, D.; Naccache, J.-M. (Bobigny)

- Titrated Sedation with Propofol for Medical Thoracoscopy: A Feasibility and Safety Study: Tschopp, J.-M. (Montana/Geneva); Purek, L.; Frey, J.-G.; Schnyder, J.-M. (Montana/Sion); Diaper, J.; Cartier, V.; Licker, M. (Geneva)

- Profiling of Sputum Inflammatory Mediators in Asthma and Chronic Obstructive Pulmonary Disease: Bafadhel, M. (Leicester); McCormick, M. (Loughborough); Saha, S. (Sheffeld); McKenna, S.; Shelley, M.; Hargadon, B.; Mistry, V.; Reid, C.; Parker, D.

(Leicester); Dodson, P.; Jenkins, M.; Lloyd, A.; Rugman, P.; Newbold, P. (Loughborough); Brightling, C.E. (Leicester)

- Long-Term Treatment with Infliximab in Patients with Sarcoidosis: Hostettler, K.E.; Studler, U.; Tamm, M.; Brutsche, M.H. (Basel)

- The Role of Bone Marrow-Derived Adult Stem Cells in a Transgenic Mouse Model of Allergic Asthma: Ou-Yang, H.-F.; Han, X.-P.; Zhao, F.; Ti, X.-Y.; Wu, C.-G. (X''an)
Respiration brings together the results of both clinical and experimental investigations on all aspects of the respiratory system in health and disease. Clinical improvements in the diagnosis and treatment of chest and lung diseases are covered, as are the latest findings in physiology, biochemistry, pathology, immunology and pharmacology. The journal includes classic features such as editorials that accompany original articles in clinical and basic science research, reviews and letters to the editor. Further sections are: technical notes, 'the eye catcher', 'what's your diagnosis', 'the opinion corner', 'new drugs in respiratory medicine', 'new insights from clinical practice' and 'guidelines'. Respiration is the official journal of the Swiss Society for Pneumology (SGP) and also home to the European Association for Bronchology and Interventional Pulmonology (EAB), which occupies a dedicated section 'interventional pulmonology' in the journal. This modern mix of different features and a stringent peer-review process by a dedicated editorial board make Respiration a complete guide to progress in thoracic medicine. 


\section{Towards a holistic way of understanding and treating asthma and allergy}

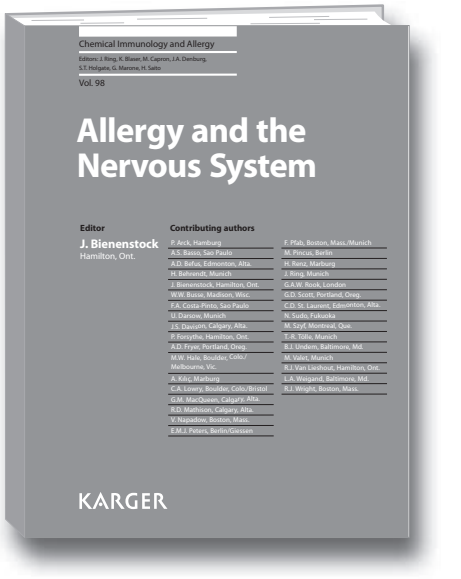

In recent decades, it has become increasingly clear that the immune and nervous systems communicate with each other in a bidirectional way. The role of chronic stress in allergic disease and inflammation has been confirmed and raises the important question of how psychosocial factors influence the outcome of allergic conditions.

This book explains the roles of the autonomic, peripheral and central nervous systems in allergy and asthma. With contributions from leading authorities - both clinicians and basic researchers - it covers a wide range of topics from psychology over epigenetics to brain imaging. The 15 invited reviews discuss topics such as the role of stress in allergy and asthma, the concept of programming in utero and in childhood and adulthood, the significance of neurotrophins, and the involvement of the nervous system in the lung in asthma and lung inflammation. The interactions between mast cells and the nervous system are examined as well as the role of the gut microbiome in regulating the hypothalamic-pituitary-adrenal axis and the stress response. Further chapters are devoted to neural and behavioral changes associated with food allergy, the role of the neuroendocrine system in the skin, and the way in which itch is processed by the brain.

Unique in its field, this valuable volume is recommended reading not only for allergologists, psychologists specializing in allergy and somatic manifestations, respirologists and asthma researchers, but for anyone interested in psychoneuroimmunology.

\section{Allergy and the Nervous System}

\author{
Editor \\ John Bienenstock
}

\section{Contents}

Preface: Bienenstock, J.

Relations between Asthma and

Psychological Distress: An Old Idea Revisited: Van Lieshout, R.J.; MacQueen, G.M.

The Brain and Asthma: What Are the Linkages?: Busse, w.W.

Stress-Related Programming of Autonomic Imbalance: Role in Allergy and Asthma: Wright, R.J.

Role of Parasympathetic Nerves and Muscarinic Receptors in Allergy and Asthma: Scott, G.D.; Fryer, A.D.

Developmental Programming of Allergic Diseases: Pincus, M.; $_{\text {Arck, }}$.

Mind-Body Interrelationship in DNA Methylation: Szyf, $\boldsymbol{M}$.

Neurotrophins in Chronic Allergic Airway Inflammation and Remodeling: $\mathbf{R e n z}, \boldsymbol{H}$.; Kılıç, $A$.

Pathways Underlying Afferent Signaling of Bronchopulmonary Immune Activation to the Central Nervous System: Hale, M.W.; Rook, G.A.W.; Lowry, C.A.

www.karger.com/chial
Allergen-Induced Neuromodulation in the Respiratory Tract: Weigand, L.A.; Undem, B.J. Role of Microbiome in Regulating the HPA Axis and Its Relevance to Allergy: Sudo, $\mathbf{N}$.

Autonomic Regulation of Anti-Inflammatory Activities from Salivary Glands:

Mathison, R.D.; Davison, J.S.; St. Laurent, C.D.; Befus, A.D.

The Mast Cell-Nerve Functional Unit: A Key Component of Physiologic and Pathophysiologic Responses: Forsythe, $\boldsymbol{P}_{\text {.; }}$ Bienenstock, J.

Neural and Behavioral Correlates of Food Allergy: Costa-Pinto, F.A.; Basso, A.S.

The Neuroendocrine-Immune Connection Regulates Chronic Inflammatory Disease in Allergy: Peters, E.M.J.

Itch and the Brain: Pfab, F.; Valet, $\boldsymbol{M}_{. ;}$ Napadow, V.; Tölle, T.-R.; Behrendt, H.; Ring, J.; Darsow, $U$.

Author Index

Subject Index

\section{Chemical Immunology and Allergy, Vol. 98} Series Editors: Ring, J. (Munich); Blaser, K. (Davos); Capron, M. (Lille); Denburg, J.A. (Hamilton); Holgate, S.T. (Southampton); Marone, G. (Naples); Saito, H. (Tokyo) ISSN 1660-2242 / e-ISSN 1662-2898

\section{Allergy and the Nervous System} Editor: Bienenstock, J. (Hamilton, Ont.) XII + 272 p., 51 fig., 4 tab., hard cover, 2012 CHF 196.- / EUR 163.- / USD 231.00 Prices subject to change EUR price for Germany, USD price for USA only ISBN 978-3-8055-9984-9 e-ISBN 978-3-8055-9985-6

\section{Please send: _ c copy/ies \\ Postage and handling free with prepayment \\ Payment: \\ Please charge to my credit card \\ $\square$ American Express $\square$ Diners \\ $\square$ MasterCard $\square$ Visa \\ Card No.: \\ Exp. date: \\ CVV/CVC \\ (3 digits in the signature field on the back of Visa and MasterCard) \\ $\square$ Check enclosed $\square$ Please bill me}

Orders may be placed with any bookshop, subscription agency, directly with the publisher or through a Karger distributor.
Date:
Fax: +41613061234

S. Karger AG, P.O. Box, CH-4009 Basel (Switzerland) E-Mail orders@karger.ch, www.karger.com

Name/Address: 